\title{
Kristīne Zaḷuma
}

\section{Nejaušas satikšanās Bikstos: grāmatās atstātās liecības}

Atslēgvārdi: Kurzemes muižas, kultūras mantojums, bibliotēku vēsture, muižas bibliotēka, ekslibris, provenience.

Daudzu Latvijas atmiņas institūciju vēsturisko krājumu grāmatas glabā atmiņas par saviem kādreizējiem īpašniekiem. Raksts veltīts Bikstu muižas (Bixten) fon der Ropu (von der Ropp) dzimtas 19. gadsimta un 20. gadsimta pirmajā pusē atstātajām liecībām grāmatās, kas cieši savijušās ar kādreizējās bibliotēkas īpašnieku un apkārtnes vietējo iedzīvotāju likteniem. Latvijas Nacionālajā bibliotēkā identificētas vairākas grāmatas ar Bikstu muižas piederīgo atstātām īpašumzīmēm un ierakstiem. To izpēte sniegusi iespēju pirmo reizi sabiedrības vērtējumam tuvplānā atklāt arī jaunas ziņas par divu 19. gadsimta beigās radītu ekslibru izcelsmi, kuru autors līdz šim uzskatīts par nezināmu. Rakstā aplūkota minēto ekslibru autora - Latvijas kultūrtelpā aizmirsta Bikstu muižā dzimuša arhitekta, mākslinieka, rakstnieka un publicista Maksa Aleksisa Alfonsa fon der Ropa (Max Alexis Alphons von der Ropp; 1876-1940) - dzīve un darbi. Konkrētu kādreizējo muižu bibliotēku iespieddarbu un tajā atstāto liecību pētniecība atklāj to izcelsmes (proveniences) sarežgìito vēsturi.

Bikstu pagasts, kurā mūsdienās atrodas kādreizējās muižas apbūve, iekḷaujas Dobeles novadā. Bikstu muižā $(1)$ fon der Ropu dzimta dzìvojusi no 1795 . līdz 1939. gadam. ${ }^{1}$

1 Bikstu muiža. Nacionālās kultūras mantojuma pārvaldes Pieminekḷu dokumentācijas centrs
Muižas jaunā kungu māja būvēta laikposmā no 1846 . līdz 1848. gadam² (kā celtniecības gadi minēti arī 1865.-1866. gads ${ }^{3}$ ) Bikstu un Sprinğgu (Springen) muižas īpašnieka Karla Teodora Alfonsa fon der Ropa (Carl Theodor Alfons von der Ropp; 1809-1883) laikā. Jau tad kungu mājā noteikta telpa bija atvēlēta bibliotēkas izvietošanai. Tās īpašnieks jau kopš 1835. gada ${ }^{4}$ bija mākslas un grāmatu pazinēju ievērojamās Kurzemes Literatūras un mākslas biedrības (Kurländische Gesellschaft für Literatur und Kunst; 1817-1939) dalībnieks.

Par pirmo "nejaušo satikšanos" Bikstos liecina Bībelē $\overline{-}^{5}$ atstāts ieraksts 2):

(turpmāk NKMP PDC), 4892: Nr. 5574; Dišlere, I. 2013. Jaunpils muižas, muižinas: Jaunpils novada muižu vēsture no 13. lìdz 20. gadsimtam. Rīga: Atēna, 132. lpp.

2 Dišlere, I. 2013. Jaunpils muižas, muižinas, 132. lpp.; Mašnovskis, V. 2018. Muižas Latvijā: vēsture, arhitektūra, māksla: enciklopēdija. 1. sēj.: A-H. Rīga: DUE, 117. lpp.

3 Bikstu muiža. NKMP PDC, 4892: Nr. 5574.

4 Sitzungsberichte der kurländischen Gesellschaft für Literatur und Kunst, 1876. 1877. Mitau: J. F. Steffenhagen und Sohn, S. 46.

5 Biblia, tas irr: Ta Swehta Grahmata, jeb Deewa Swehti Wahrdi, Kas preeksch un pehz ta Kunga Jesus Kristus swehtas Peedsimschanas no teem swehteem Deewa-Zilwekeem, Praweescheem, Ewangelisteem jeb Preezas-Mahzitajeem un Apustuleem usrakstiti, Tahm Latweeschahm Deewa Draudsibahm par labbu istaisita. 1825. Peterburgâ: drikkkehts pee T. Rutta un dehla, 10, [2], 992, 174, [2], 338 lpp. Eksemplārs: Latvijas Nacionālā bibliotēka (turpmāk LNB), svìtrkods: 0317112871. 


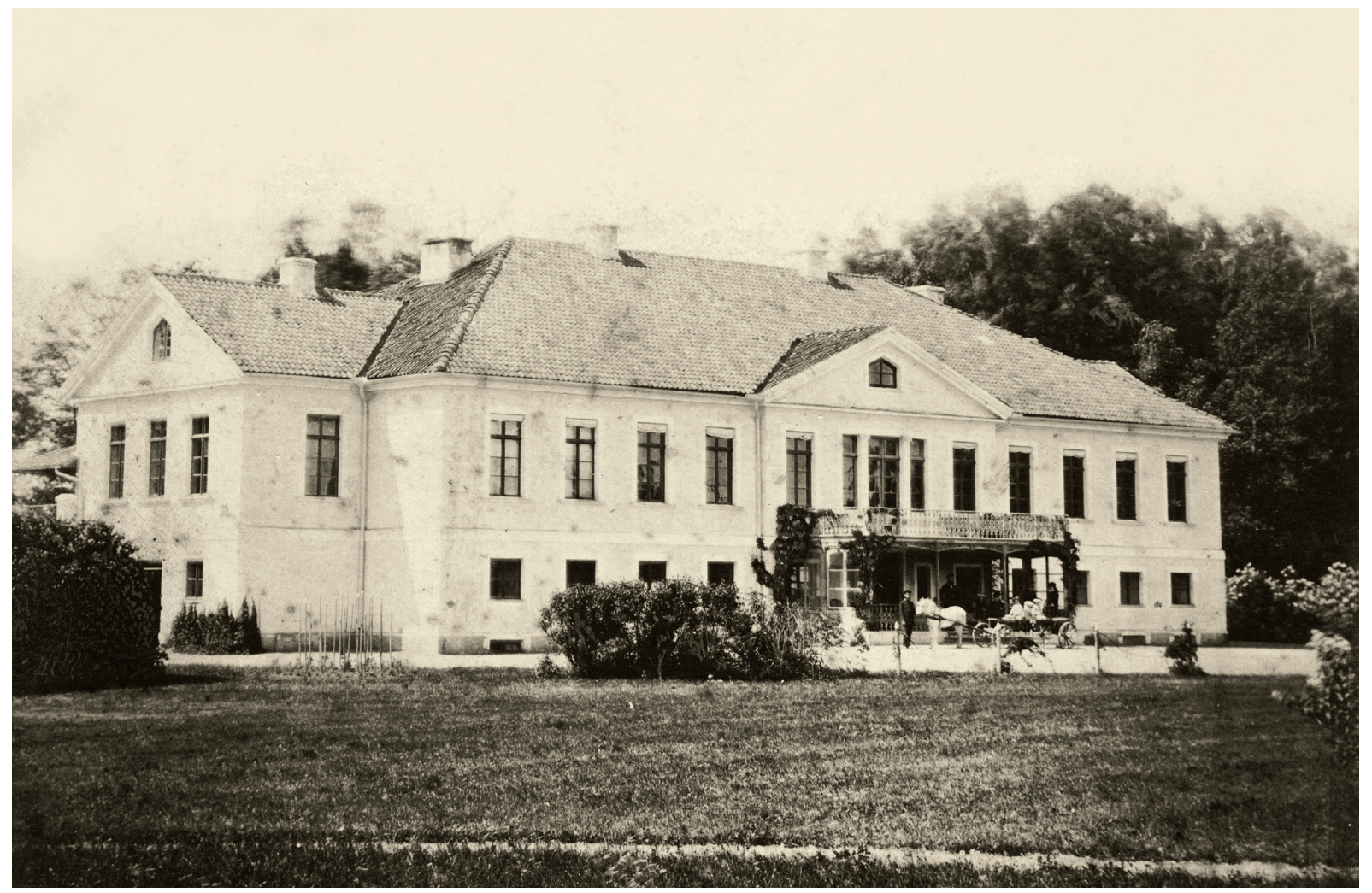

(1) Bikstu muižas kungu māja, 20. gadsimta sākums. LU AB

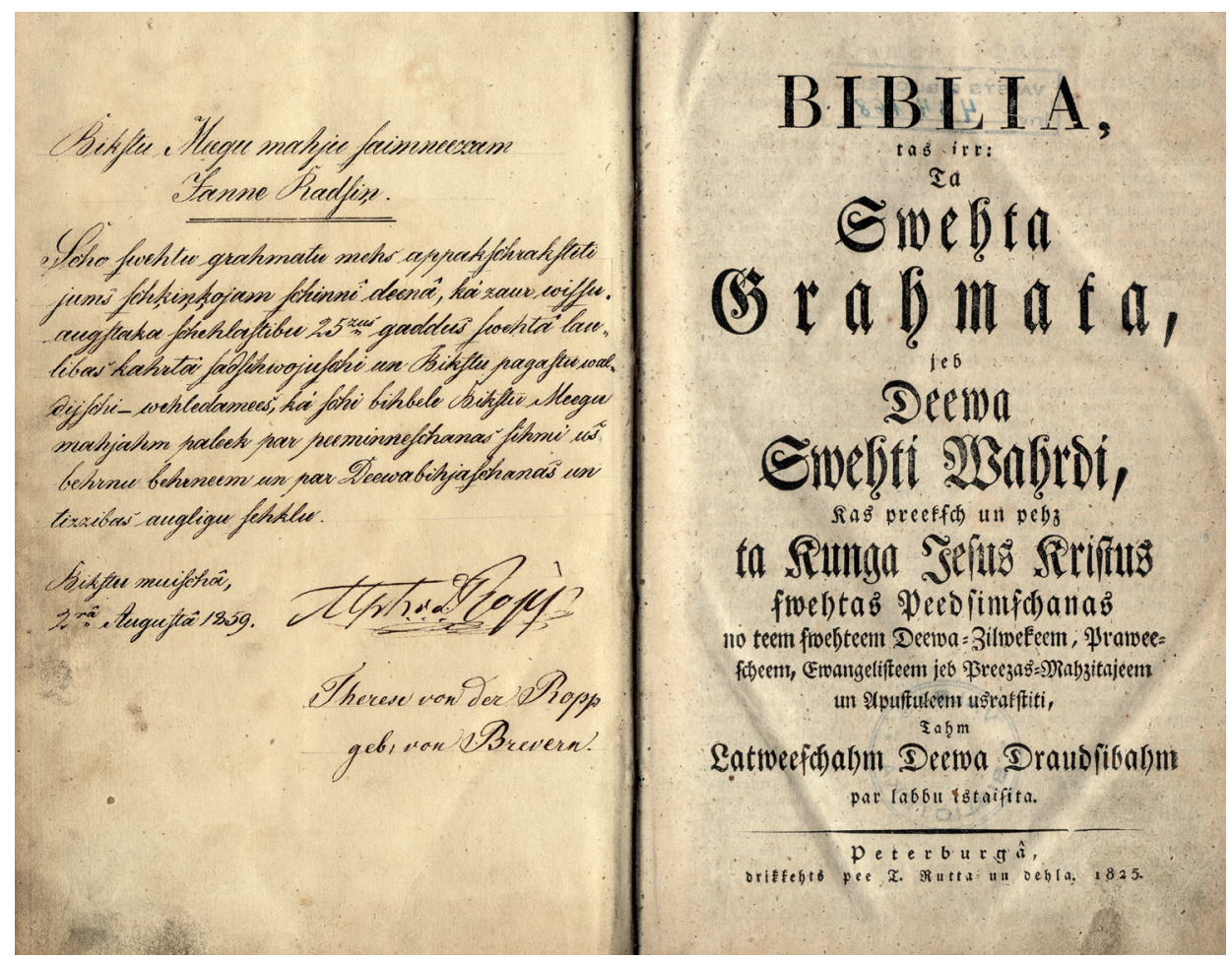

2 Bībele ar Bikstu muižas īpašnieku Karla Teodora Alfonsa fon der Ropa un Terēzes Katarīnas Amālijas fon der Ropas ierakstu, 1859. LNB 
Karls Teodors Alfonss fon der Rops un viņa dzīvesbiedre Terēze Katarīna Amālija fon der Ropa, dzimusi fon Brēverna (Therese Catharina Amalie von der Ropp, geboren von Brevern; 1814-1883), atzìmējot 25. kopdzìves gadadienu 1859. gada 2. augustā, dāvinājuši grāmatu Bikstu pagasta Miegu māju saimniekam Jānim Radziṇam: "Bikstu Miegu māju saimniekam Jānim Radziṇam. Šo svētu grāmatu mēs apakšrakstīti jums šķin,k,ojam šinī dienā, kā caur visu, augstāka žēlastību 25cus gadus svētā laulības kārtā sadzīvojuši un Bikstu pagastu valdījuši vēlēdamies, ka šī Bībele Bikstu Miegu mājām paliek par pieminēšanas zīmi uz bērnu bērniem un par Dievabijāšanas un ticības auglīgu sēklu. Bikstu muižā, 2rā Augustā 1859. Alph. v. d. Ropp. Therese von der Ropp, geb. von Brevern." Nesagaidot zelta kāzas, abi fon der Ropi devās mūžībā vienā gadā - vispirms cienmāte, bet pēc vairākiem mēnešiem arī vinas vīrs.

Bez Bikstu muižas īpašnieku ieraksta Bībeles iekšējā priekšējā vākā atrodams ekslibris, kas grāmatā ielīmēts 73 gadus pēc tam, kad tapis aprakstìtais fon der Ropu ieraksts. Mākslinieka Riharda Kārḷa Valdemāra Zarina (arī Rihards Zariņš; Kārlis Richards Valdemārs Zarriņš; Richards Zarrinšs, 1869-1939) 1925. gadā veidotais ekslibris (krāsaina cinkogrāfija, $14 \times 10 \mathrm{~cm}$ ) 3 "J. Missiņa īpašums. Es gribu izsmelt jūru... Skap[is]. Nr.” liecina, ka grāmata Latvijas Nacionālās bibliotēkas krājumā nonākusi no pazīstamā bibliofila un bibliogrāfa, pirmā Valsts bibliotēkas (mūsdienās Latvijas Nacionālā bibliotēka) pārziṇa (direktora; 1919. gada septembris - 1920. gada maijs) Jāna Misina (1862-1945) privātbibliotēkas. Zem ekslibra grāmatas īpašnieks J. Misinšs ar zīmuli pašrocīgi ierakstījis, ka izdevums dāvināts 1932. gadā un tā dāvinātāja bijusi "Steinberg jkze (Rakstniece Amaranta) ${ }^{6}$.

Nākamās nejaušās un nozīmīgākās satikšanās Bikstos saistītas ar diviem ekslibriem, kuru

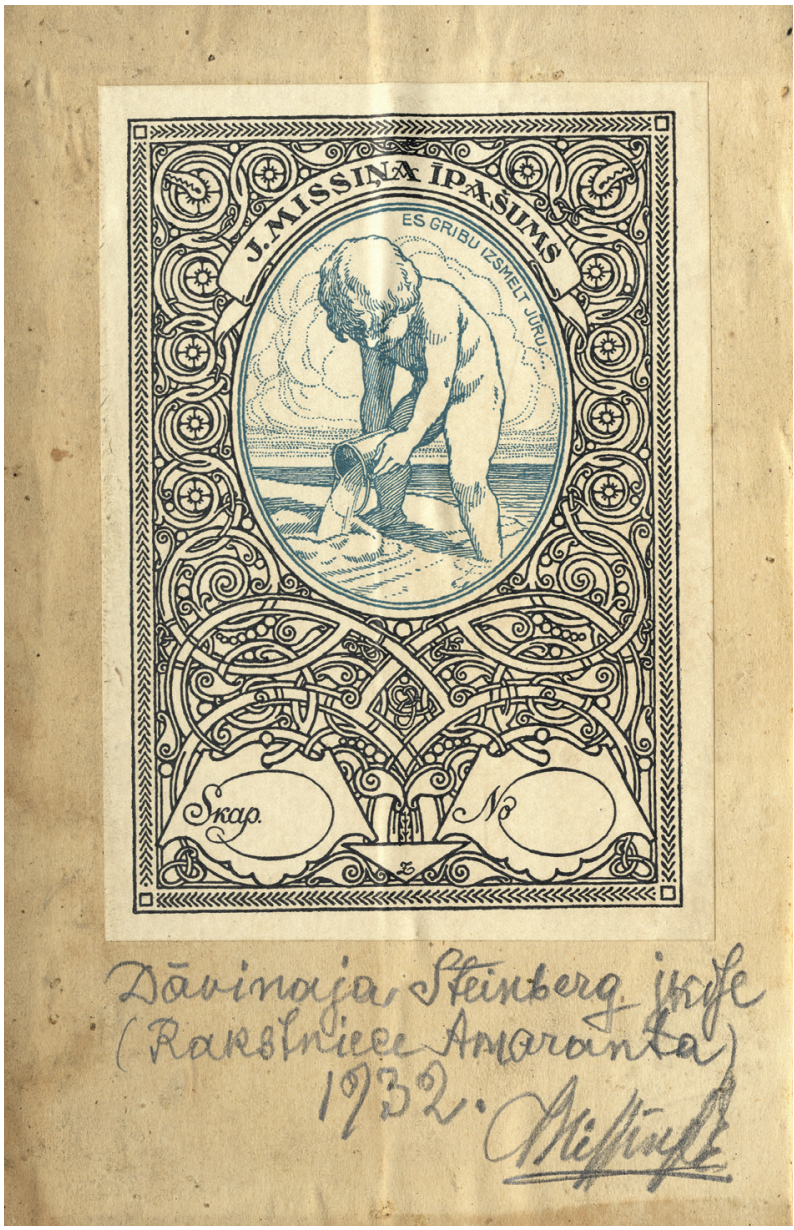

Rihards Zarinšs. Jāṇa Misiṇa ekslibris, 1925. LNB

6 Uzticamus datus par rakstnieci neizdevās atrast, zināms, ka ar šādu vārdu 20. gadsimta 20. un 30. gados publicējusies tulkotāja. 
autors līdz šim uzskatīts par nezināmu. Abi ekslibri, kas tapuši 1899. gadā, kā Maksa Aleksisa Alfonsa fon der Ropa darbi norādīti rokasgrāmatā, kas izdota 1901. gadā. ${ }^{7}$ Līdz šim nevienā publikācijā mākslinieka vārds nav bijis saistīts ar Latvijas teritoriju, parasti viņš norādīts kā vācu grafikikis.

Arhitekts un mākslinieks, arī rakstnieks un publicists, vēlāk fermeris Dienvidāfrikā, Namībijas galvaspilsētā Vindhukā (Windhuk), Makss Aleksiss Alfonss fon der Rops 4 bija Bikstu muižas īpašnieka, augstākās sabiedrības aprindās pazīstamā Georga Morica Maksa fon der Ropa (Georg Moritz Max von der Ropp; 1850-1919) un viṇa sievas, Zaḷajā muižāà (Grünhof) dzimušās Marijas Irēnes Emīlijas fon der Ropas, dzimušas fon Šepingas op dem Hammes (Marie Irene Emilie op dem Hamme genannt Schöppingk; 1856-1928), vecākais bērns un kungu mājas cēlāja Karla Teodora Alfonsa fon der Ropa mazdēls. Mākslinieka Maksa Aleksisa Alfonsa fon der Ropa tēva un mātes kāzu dienas attēls 1875. gada 18. jūnijā 5 rāda grāmatas un mākslas vietu un nozīmīgumu jaunā pāra dzīvē. Šajā laikā Bikstu muižas kungu mājas bibliotēkai bija atvēlēta telpa kungu mājas dienvidu gala tālākajā vietā, līdzās ēdamistabai vienā rindā ar puḳu un rotaḷu istabu. ${ }^{8}$

Kā liecina ieraksts Minhenes Mākslas akadēmijas studentu matrikulā, Makss Aleksiss Alfonss fon der Rops 1900. gada 25. aprīlī uzsācis studijas glezniecībā kā vācu mākslinieka, pazīstamā portretista un monumentālista, akadēmijas profesora Ludviga fon Herteriha (Ludwig von Herterich; 1856-1932) skolnieks. ${ }^{9}$

7 Deutsche und österreichische Bibliothekzeichen Exlibris. Ein Handbuch für Sammler, Bücher- und Kunstfreunde 1901. Stuttgart: Julius Hoffmann, S. 418.

8 Bikstu muiža. NKMP PDC, 4892: Nr. 5574.

9 Akademie der Bildenden Künste München. Matrikelbücher 1809-1935: 02112 Max Alexis v. d. Ropp. Pieejams: https://matrikel.adbk.de/matrikel/ mb_1884-1920/jahr_1900/matrikel-02112 [skatìts 10.01.2020.].

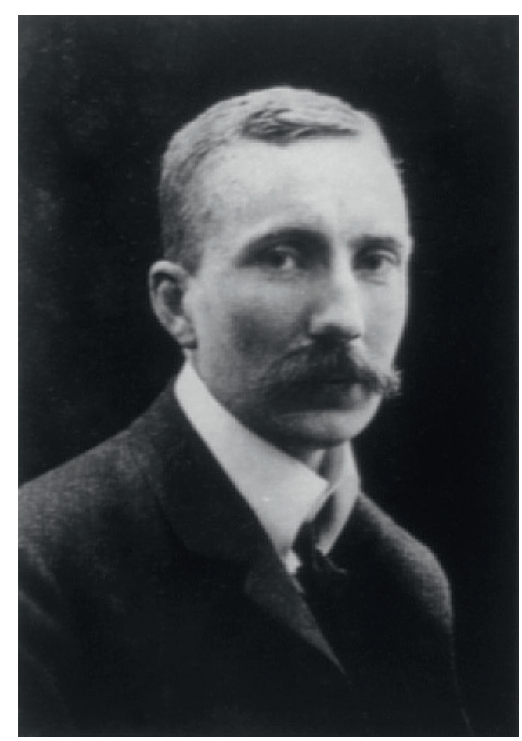

Makss Aleksiss Alfonss fon der Rops, 20. gadsimta sākums. Fotokopija. Mārburgas fotoarhīvs, Baltijas bruṇniecības apvienība

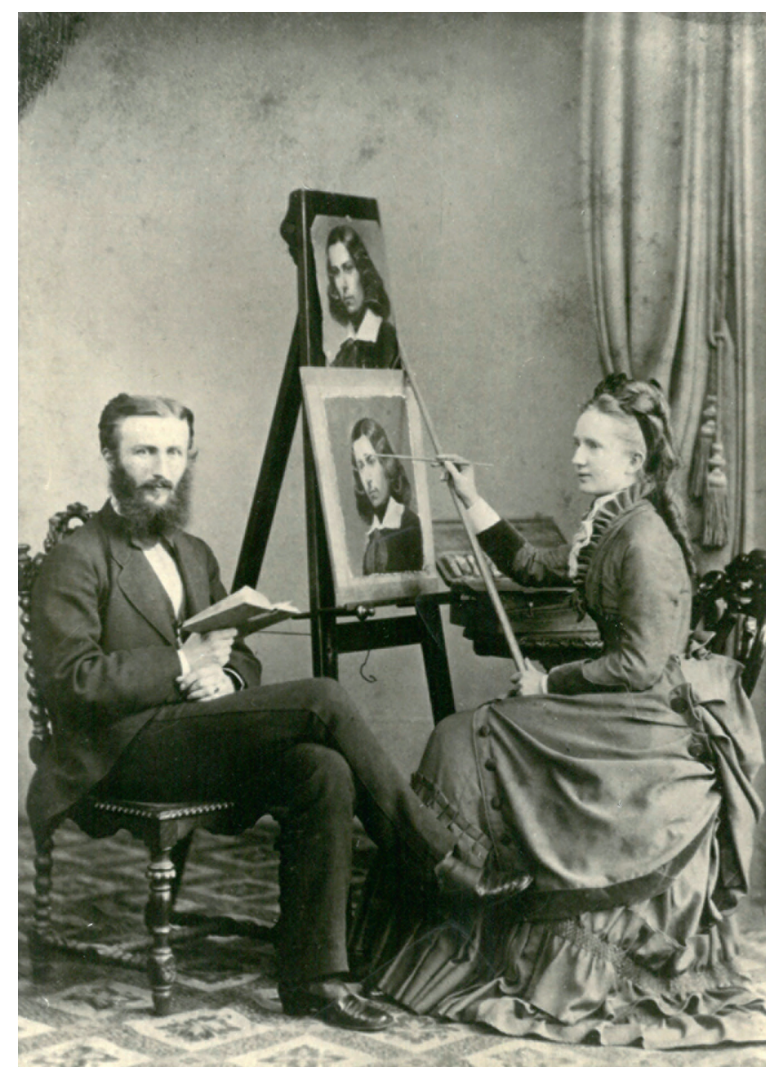

5 Georgs Morics Makss fon der Rops un Marija Irēne Emīlija fon der Ropa kāzu dienā, 1875.

Fotokopija. LNB 
Latvijā visbiežāk Maksa Aleksisa Alfonsa fon der Ropa vārds pieminēts saistībā ar Jaunauces muižas (Neu-Autz) kungu māju. ${ }^{10} 1903$. gadā pēc viņa projekta kungu mājas interjers daḷēji tika atjaunots (ēdamzāles bufetes niša ar Partenona motīviem, ovālās zāles ciḷni un kupola gleznojums) ${ }^{11}$, atdodot skaistajai Kurzemes klasicisma celtnei historisma laikmetā daḷēji zaudēto stila vienību. ${ }^{12}$ Ar pietāti risinot neoklasicisma stila izvirzītās laikmeta aktualitātes, arhitekts mazāk pievērsies antīko formu detal̦ām, bet vairāk uzsvēris interjera apjomu gleznieciskumu un plastiku. ${ }^{13}$ Mūsdienās Jaunauces muižas apbūve ir 19. gadsimta valsts nozīmes arhitektūras piemineklis. Vienīgais Latvijā apbrīnojami neskartā stāvoklī saglabājies vēlīnā klasicisma interjeru paraugs.

Mākslinieks un arhitekts Makss Aleksiss Alfonss fon der Rops bija arī pazīstams publicists un rakstnieks. Viṇa romāns "Elkesragge" ("Elkurags") ${ }^{14}$ vēsta par 1905. gada revolūcijas notikumiem Latvijā, un viņš ir arī plašu un nozīmīgu rakstu autors. Publikācijās viņš aprakstījis muižu un to kultūras vērtību likten,us pēc

10 Brug̣is, D. 2008. Die Herrenhäuser des Neoklassizismus in Lettland und ihre stilistischen Wurzeln in der Baukunst von Kurland und Livland. In: Klassizismus im Baltikum: neun Beitrage zum 5 Baltischen Seminar 1993. Lüneburg: Carl-SchirrenGesellschaft, S. 143 (Schriftenreihe Baltischen Seminare, Bd. 3); Brugis, D. 1997. Historisma pilis Latvijā. Atk. izd. Rīga: Sorosa fonds-Latvija, 217. lpp.

11 Lancmanis, I. 2019. Arhitektūra 1780-1840. Latvijas māksslas vēsture. 3. sēj. 1. grām. Klasicisma un romantisma periods 1780-1840. Rīga: Latvijas Mākslas akadēmijas Mākslas vēstures institūts; Mākslas vēstures pētījumu atbalsta fonds, 261. lpp.; Pirang, H. 1928. Das Baltische Herrenhaus. Bd. 2: Die Blütezeit um 1800. Riga: Jonck \& Poliewsky, S. 38.

12 Brugíis, D. Historisma pilis Latvijā, 217. lpp.

13 Vairāk: Zilgalvis, J. 1995. Latvijas muižu klasicisma arhitektūra. Latvijas Vēstures Institūta Žurnāls, Nr. 1, 24.-38. lpp.

14 Ropp, M. A. v. d. 1907. Elkesragge: ein baltischer Zeitroman. Berlin: E. Fleischel \& Co, 292 S.; Ropp, M. A. v. d. 1908. Elkesragge: ein baltischer Zeitroman. 2. Aufl. Berlin: Fleischel, 289 S.
1905. gada revolūcijas notikumiem ${ }^{15}$, izmēǵinājis roku literatūrkritikā un turpinājis rakstīt literārus sacerējumus ${ }^{16}$, sniedzis ieskatu vācbaltiešu mākslinieku sasniegumos Latvijā un Vācijâa ${ }^{17}$, bet vēlākajā publicistikas posmā aprakstījis Dienvidāfrikas iedzīvotāju problēmas. ${ }^{18}$

Kā arhitekts Makss Aleksiss Alfonss fon der Rops 1912./1913. gadā ar labiem panākumiem piedalījās Rīgas Vācu strēlnieku apvienības (Rigaer Schützenverein; 1858-1939) jaunā nama celtniecības skiču konkursā. ${ }^{19}$ Lai gan viņš ieguva godalgu, piedāvātā iecere tomēr nekad netika realizēta.

Pirmais ekslibris tapis īsi pirms studiju laika Minhenē, 1899. gadā (kḷūdaini datēts arī ar 1900. gadu' ${ }^{20}$ ). Mākslinieks Makss Aleksiss Alfonss fon der Rops to veidojis sava tēva Georga Morica Maksa fon der Ropa plašās bibliotēkas krājuma vajadzībām Bikstu muižā. Ekslibrī (cinkogrāfija, 11,8 × 9,1 cm) 6 attēlots zinātnieks un bruṇinieks.

15 Ropp, M. A. v. d. 1907. Das baltische Landhaus. Düna Zeitung, Nr. 172, 27. Jul. (9. Aug.), S. 2; Nr. 173, 28. Jul. (10. Aug.), S. 2.

16 Ropp, M. A. v. d. 1921. Eines Philosophen Reisetagebuch. Rigasche Rundschau, Nr. 165, 26. Jul., S. 5; Ropp, M. A. v. d. 1923. Das Recept des Wet-Heng-Pong. Rigasche Rundschau, Nr. 211, 24. Sept., S. 6; Nr. 212, 25. Sept., S. 6.

17 Ropp, M. A. v. d. 1924. Deutschbaltische Malerei und Graphik. Ausstellung im Kunstmuseum. Rigasche Rundschau, Nr. 16, 19. Jan., S. 10.; Ropp, M. A. v. d. 1926. Baltische Künstler in Deutschland. In: Jahrbuch des baltischen Deutschtums, 1927. Riga: Jonck \& Poliewsky, S. 146-151.

18 Ropp, M. A. v. d. 1928. Südafrikanische Bevölkerungsprobleme. Rigasche Rundschau, Nr. 161, 21. Jul., S. 9; Nr. 167, 28. Jul., S. 5; Nr. 173, 4. Aug., S. 5.

19 Die Preisausschreiben des Jahres 1912-13. 1913. In: Jahrbüch fur Bildende Kunst in den Ostseeprovinzen. 7 Jahrgang. Riga: Architektenverein zu Riga, S. 81.

20 Иваск, У. Г. 1905. Описание русских книжных знаков: (Ex-Libris). Вып. 1. Москва: М. Я. Параделов, с. 243-244; Piilmann, S., Becker, P. G. 2002. Baltische Wappenexlibris: Exlibris der Ostseeprovinzen: Estland-Kurland-Livland-Ösel. Tallinn; Gütersloh: [b. i.], S. 72. 

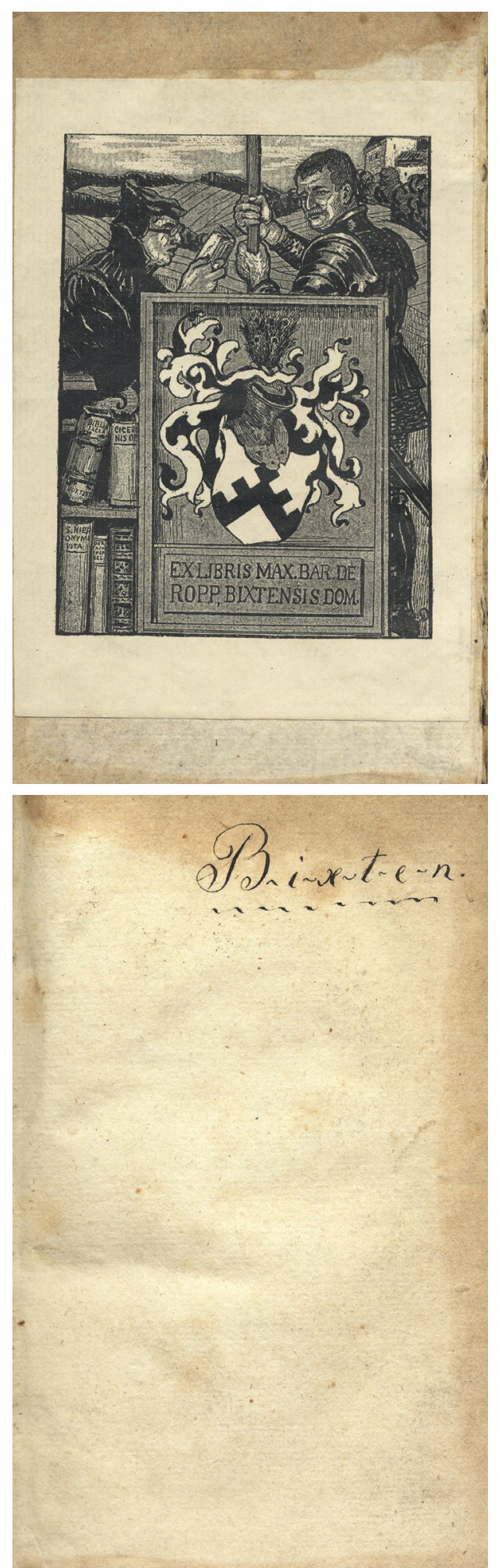

Makss Aleksiss Alfonss fon der Rops. Bikstu muižas īpašnieka Georga Morica Maksa fon der Ropa bibliotēkas ekslibris, 1899. LNB
Abi zīmēti uz senas bibliotēkas fona kā norāde uz to, ka muižas bibliotēkas krājums bija sens un zinātniski ievirzīts. Ekslibra vidū fon der Ropu dzimtas ǵerbonis ar uzrakstu "EX LIBRIS MAX. BAR. DE ROPP, BIXTENSIS DOM." (Barona Maksa fon der Ropa ekslibris, Bikstu muiža) zem tā. Bruṇucepurei kleinodā piestiprinātas pāvu spalvas, fon der Ropu vairogs raksturīgi dalīts ar dzeguliem un augšā ar zarotu ševronu.

Mākslinieka tēvs Georgs Morics Makss fon der Rops ${ }^{21}$, kuram Bikstu muižas kungu mājā glabājās vērtīga bibliotēka, bija mācījies Bērzaines ǵimnāzijā (Gymnasium zu Birkenruh; 1860-1864), turpinājis izglìtoties Jelgavas ǵimnāzijā (1865-1869), bet pēc tam studējis lauksaimniecības zinības ārzemēs. Mācoties Jelgavas ǵimnāzijā, viņš sadraudzējās ar vēlāk pazīstamo mācītāju un literātu Kārli Kundziņu (1850-1937), ar kura palīdzību sekmīgi pilnveidoja latviešu valodas prasmes. ${ }^{22}$ Laikposmā no 1882. līdz 1888. gadam Georgs Morics Makss fon der Rops bija Irlavas skolotāju semināra kurators ${ }^{23}$, bet no 1889. lìdz 1901. gadam viṇš ieṇēma Kurzemes brunniecības maršala amatu, atbildot par brunniecības pašpārvaldes darījumiem. Laikposmā no 1902. līdz pat 1919. gadam vinš pildīja Kurzemes muižnieku kredītbiedrības (Kurländischen Creditverein, arī Kurländischen Kreditverein; 1830-1921) direktora amatu.

Muižas bibliotēkas īpašnieks Georgs Morics Makss fon der Rops atbilstoši interesēm bija vairāku tālaika nozīmīgu biedrību dalībnieks - kopš 1876. gada ${ }^{24}$ Kurzemes Literatūras

21 Pirang, H. 1926. Das Baltische Herrenhaus. Bd. 1: Die älteste Zeit bis um 1750. Riga: Jonck \& Poliewsky, S. 61; Album Curonorum: 1808-1932. 1932. Riga: Historischen Kommission der Curonia, S. 127.

22 Lapiņš, J. 1929. Kārlis Kundziņš sen. Atskats uz dzīvi un 60 gadu literārisko darbību. Izglittibas Ministrijas Mēnešraksts, Nr. 1, 3. lpp.

23 Vičs, A. 1922. Irlavas skolotāju seminārs. Izglïtības Ministrijas Mēnešraksts, Nr. 11, 1136. lpp.

24 Sitzungsberichte der kurländischen Gesellschaft für Literatur und Kunst, 1876. 1877. S. 49. 
un mākslas biedrības (kopš 1894. gada ${ }^{25}$ arī biedrības G̣enealogijas, heraldikas un sfragistikas sekcijas) dalïbnieks, bet kopš 1893. gada Krievijas Baltijas provinču vēstures un senatnes pētītāju biedrības (Gesellschaft für Geschichte und Alterthumskunde der Ostprovinzen Rußlands; 1834-1939) biedrs. ${ }^{26}$

20. gadsimta sākumā, kad Bikstu muižas kungu mājā atradās arī tur iekārtotā bibliotēka, muižas īpašnieks ar ǵimeni tajā uzturējās ar pārtraukumiem, jo par pastāvīgu dzīvesvietu bija izvēlējušies dzimtai piederošos namus Jelgavā: galvenokārt Raiṇa ielā 11, 27 un 46, Jāņa Bisenieka ielā 41, Upes ielā 12 un Zemgales prospektā $1 .{ }^{27}$

Pirmā pasaules kara (1914-1918) laikā, no 1915. līdz 1918. gadam, Georgs Morics Makss fon der Rops kā bēglis pavadīja laiku Vidzemē. Atgriezies mājās Jelgavā, vin̄š vairs nevēlējās nekur bēgt un palika uz vietas pilsētā. Kad dēli viṇu mēgoinājuši pierunāt doties bēgḷu gaitās, viņš atbildējis, ka viņam pašam iztikai līdzekḷi būtu pietiekami, bet kredītbiedrības darbiniekiem diemžēl ne, tāpēc viņš paliks pilsētā. ${ }^{28}$ Domājams, ka ap šo laiku dzimteni pameta Bikstu muižas īpašnieku vecākais dēls mākslinieks Makss Aleksiss Alfonss fon der Rops.

25 Verzeichniss der Mitglieder der Section für Genealogie, Heraldik und Sphragistik in Mitau. 1893. In: Jahrbuch für Genealogie, Heraldik und Sphragistik, 1894. Mitau: J. F. Steffenhagen und Sohn, S. 176.

26 Sitzungsberichte der Gesellschaft für Geschichte und Alterthumskunde der Ostseeprovinzen Russlands aus dem Jahre 1894. 1895. Riga: W. F. Häcker, S. 219.

27 Bikstu muiža. NKMP PDC, 4892: Nr. 5574; Melderis, G. Jelgavas vēstures materiāli: izraksti un piezīmes. Rìga, 1949.-1959. LNB RXA52,9. Norādītie ielu nosaukumi un māju numuri Jelgavā atbilstoši laikam no 1929. līdz 1949. gadam.

28 Schlau, K. O. 1999. Bolschewikenzeit in Mitau: 9. Januar - 18. März 1919. Wedemark-Elze: Harro V. Hirschheydt, S. 17. (Beiträge zur baltischen Geschichte; Bd. 18.)
Viņa tēvu Georgu Moricu Maksu fon der Ropu nogalināja 1919. gada 18. martā ${ }^{29}$ sarkanā terora laikā.

Latvijas vēsturisko notikumu gaitā laikposmā no 1920. līdz 1939. gadam fon der Ropu dzimtas piederīgie joprojām dzīvoja arī Bikstos, mitinoties valsts neatsavinātās muižas daḷas ēkās. ${ }^{30}$ Tūlìt pēc Neatkarības kara (1918-1920) Bikstu muižas kungu mājā desmit skapjos joprojām atradās bibliotēka, interjerā bija saglabājušās virkne gleznu kopiju, klavieres un mēbeles. ${ }^{31}$

Pēdējais muižas īpašnieks, mākslinieka Maksa Aleksisa Alfonsa fon der Ropa brālis Ferdinands Volfgangs Pauls Erihs fon der Rops (Ferdinand Wolfgang Paul Erich von der Ropp; 1879-1969), braucot projām no Latvijas ar gimeni 1939. gada 23. novembrīi ${ }^{32}$, muižas bibliotēkas grāmatu krājumu nodeva Bikstu pagasta valdes pārvaldībā, kas to savukārt atdeva glabāšanai Bikstu sešklasīgās pamatskolas bibliotēkai. Fon der Ropu dzimtas atstātajā Bikstu muižas bibliotēkas krājumā bija

29 Gemartert und ermordet. Liste Nr. 1. 1919. Rigasche Zeitung, Nr. 22, 20. Jun., S. 5; Lielinieku upuri. 1919. Lìdums (pielikums), Nr. 16, 26. jūnijs, 18. lpp.; [Nachruf]. 1924. Rigasche Rundschau, Nr. 252, 5. Nov., S. 7; Chronik. 1925. In: Jahrbuch und Kalender des Deutschtums in Lettland 1926. Riga: Jonck \& Poliewsky, S. 109; Schlau, K. O. 1999. Bolschewikenzeit in Mitau: 9. Januar - 18. März 1919, S. 61. Lìdz 1924. gadam Georgs Morics Makss fon der Rops skaitījās bezvēsts pazudis. Vina mirstīgās atliekas atrada mežā, netālu no Jelgavas.

30 Bikstu muiža. NKMP PDC, 4892: Nr. 5574; Dišlere, I. 2013. Jaunpils muižas, muižinas, 132. lpp.

31 Pārskats par kultūras vērtību aizsardzības darbiem Kurzemē, 1919. gada decembris - 1920. gada februāris. Latvijas Nacionālā arhīva Latvijas Valsts vēstures arhīvs, 1632. f. (Izglītības ministrijas sarakste ar Arhīvu-bibliotēku nodalı par arhīva dokumentu reevakuāciju), 2. apr., 935. 1., 2. lp.

32 Izcel,ojušo vācu tautibas pilsoṇu saraksts: ziṇas par personām, kas izcelojušas saskañā ar lïgumu par vācu tautïbas Latvijas pilsonu pārvietošanu uz Vāciju: (Lik. kr. 1939. g. 176.): oficiāls izdevums. 1940. [Rīga]: Iekšlietu ministrijas administratîvais departaments, 1230. lpp. 
ap 2000 sējumu, galvenokārt 18. un 19. gadsimta izdevumi greznos iesējumos angḷu, franču un vācu valodā. ${ }^{33}$

Latvijas Lauksaimniecības kameras (Jelgavā) bibliotekārs agronoms Kārlis Ozols (arī Eihvalds; Eichvalds) vēstulē Valsts bibliotēkas direktoram Mārtiņam Stumbergam (1872-1955) 1940. gada 26. jūnijā rakstījis: "Lielākā daḷa no sējumu skaita ir literatūra, dabas zinātnes un enciklopēdiska vērtīgos stila sējumos. Minētās grāmatas skolai nav vajadzīgas, un telpu trūkuma dēḷ tās novietotas jumta paspārnē, kamdēl skola labprāt tās nodotu piekritīgām iestādēm." ${ }^{34}$ 1940. gada jūlijā šo grāmatu krājumu nodeva Valsts bibliotēkas pārzin̄ā. Latvijas Nacionālās bibliotēkas krājumā ir identificētas un joprojām glabājas vairākas grāmatas ${ }^{35}$ ar Georga Morica Maksa fon der Ropa Bikstu muižas bibliotēkas vajadzībām tapušo ekslibri.

Otrs Maksa Aleksisa Alfonsa fon der Ropa pirms studijām Minhenē radītais ekslibris (krāsaina cinkogrāfija, 14,2 x 8,7 cm) 7 atrodams Zaḷās muižas grāfienes, viņa vecmāmiņas

33 Sarakste ar Izglìtības ministriju par Valsts bibliotēkas pārvaldīšanu, 1925-1941. Latvijas Nacionālā arhìva Latvijas Valsts arhīvs, 235. f. (Latvijas Republikas Kultūras ministrijas Latvijas Nacionālā bibliotēka, 1919-1995), 1a. apr., 5. 1., 182.-184. lp. 34 Turpat, 184. lp.

35 Piem.: Retz, J. F. de. Mémoires du cardinal de Retz: contenant Ce qui s'est passé de remarquable en France pendant les premières années du Règne de Louis XIV. Tome 1., 3., 4. 1719. Nouv. ed. Amsterdam: Chez J. Frederic Bernard, et H. Du Sauzet. Eksemplāri: LNB; Fenelon, de Salignac de La Mothe. 1730. Les Aventures de Télémaque, fils d'Ulysse. Nouv. édition. Paris: Bartelemy, XXXIII p., 504 p.; Bielfeld, J. F. von. 1767. Les Premiers traits de l'Erudition Universelle, ou analyse abrégée de toutes les sciences, des beaux-arts et des belles lettres, par M. Le Baron de Bielfeld. T. 2. Leide: Chés Sam. et Jean Luchtmans, 350 p. Eksemplārs: LNB; Petri, J. Ch. 1809. Neue Pittoresken aus Norden, oder Statistisch-historische Darstellungen aus Lief- Ehst- und Russland: nebst einer Topographie von Moskau. 2., stark vermehrte Aufl. Erfurt: Knick und Müller, VIII, 378 p. Eksemplārs: LNB, svītrkods 0311071199 (grāmata pārsieta, saglabājies tikai ekslibris).

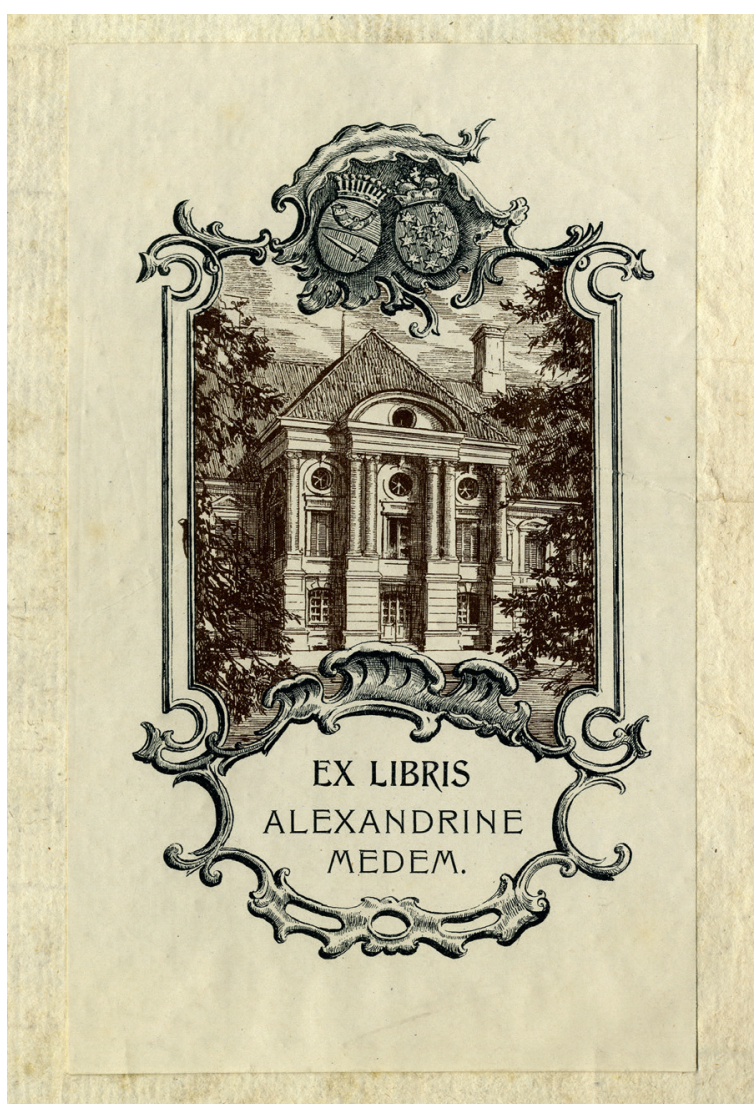

Makss Aleksiss Alfonss fon der Rops. Zạ̣ās muižas īpašnieces Aleksandrīnes Elīzes Dorotejas fon Mēdemas bibliotēkas ekslibris, 1899. LNB 
no mātes puses, Aleksandrīnes Elīzes Dorotejas fon Mēdemas, atraitnes fon Šepingas op dem Hammes, dzimušas fon Livenas (Alexandrine Elise Dorothea von Medem, verwitwet von Schoppingk op dem Hamme, geborene von Lieven; 1831-1913), privātbibliotēkas grāmatās. Ekslibris tapis 1899. gadā (kḷūdaini datēts arī ar 1904. gadu ${ }^{36}$ ), un tajā atspogul,ota fon Mēdemu Zaḷās muižas pils fasādes centrālā daḷa, bet tā augšējā daḷā divi ǵerboṇi - pa kreisi grāfu fon Mēdemu, pa labi firstu fon Lìvenu -, un ekslibra centrā redzams uzraksts "EX LIBRIS ALEXANDRINE MEDEM".

1913. gada 27. decembrī Zaḷās muižas īpašniece Aleksandrīne Elīze Doroteja fon Mēdema aizmiga mūža miegā. İpašumu mantoja viena no viņas mazmeitām. Neskatoties uz vācu kareivju postījumiem muižā Pirmā pasaules kara pirmajos gados, vēl kara beigās tajā atradās iespaidīgs grāmatu krājums, kas bija izvietots trīs pils telpās. Bibliotēkā glabājās izcila reliǵiskās literatūras kolekcija, kā arī memuārliteratūra, grāmatas par ǵeogrāfiju, ceḷošanu, mākslu un vēsturi. Kā īpaši vērtīga krājuma daḷa bija grāmatas par Baltijas vēsturi. 1919. gadā Latvijas armijas kareivji sapakoja un šīs bibliotēkas grāmatas

\section{AVOTI UN LITERATŪRA}

Akademie der Bildenden Künste München. Matrikelbücher 1809-1935: 02112 Max Alexis v. d. Ropp. Pieejams: https://matrikel.adbk.de/matrikel/ mb_1884-1920/jahr_1900/matrikel-02112 [skatīts 10.01.2020.].

Album Curonorum: 1808-1932. 1932. Riga: Historischen Kommission der Curonia.

36 Иваск, У. Г. 1905. Описание русских книжных знаков: (Ex-Libris). Вып. 1., с. 183-184; Piilmann S., Becker P. G. 2002. Baltische Wappenexlibris, S. 58; Zaluma, K. 2019. Neredzamā bibliotēka: Latvijas Nacionālās bibliotēkas 14 vēsturiskās kolekcijas. Rīga: Latvijas Nacionālā bibliotēka, 212. lpp. nosūtīja Latvijas Pagaidu valdības Izglītības ministrijai uz Rīgu. Vēlāk daḷa no grāfienes bibliotēkas grāmatām nonāca Valsts bibliotēkā. ${ }^{37}$

Bikstu muižas dzīvē un kultūras vērtību likteņos būtiskas izmaiņas ienesa nevienu nesaudzējošie kari - daḷa muižas l̦aužu devās bēgḷu gaitās, bet īpašnieks Georgs Morics Makss fon der Rops zaudēja dzīvību. Plašās pasaules izaicinājumiem Pirmā pasaules kara laikā padevās Vācijā izglìtotais talantīgais mākslinieks un arhitekts Makss Aleksiss Alfonss fon der Rops, uz ilgiem gadiem pazaudējot saikni ar dzimteni un laujot Latvijā aizmirst savu vārdu. Pavisam nejaušas satikšanās Bikstos šajā rakstā izveidojušas vienotu stāstu par muižas īpašnieku fon der Ropu dzimtu un vinu bibliotēkas likteni, sniedzot iespēju ar lìdz šim maz izmantotu avotu palīdzību ieraudzìt muižas un tās bibliotēkas nezināmās vēstures lappuses, personalizējot un no aizmirstības glābjot grāmatās atrodamu ekslibru autoru.

Pētījums izstrādāts Valsts pētījuma programmas projekta "Dokumentārā mantojuma izpētes nozìme, veidojot sinerợijas starp pētniecību un sabiedrību" (Nr. VPP-IZM-2018/1-0022) ietvaros.

Biblia, tas irr: Ta Swehta Grahmata, jeb Deewa Swehti Wahrdi, Kas preeksch un pehz ta Kunga Jesus Kristus swehtas Peedsimschanas no teem swehteem Deewa-Zilwekeem, Praweescheem, Ewangelisteem jeb Preezas-Mahzitajeem un Apustuljeem usrakstiti, Tahm Latweeschahm Deewa Draudsibahm par labbu istaisita. 1825. Peterburgâ: drikskehehts pee T. Rutta un dehla.

37 Vairāk: Zaļuma, K. Neredzamā bibliotēka, 204.-217. 1pp. 
Bielfeld, J. F. von. 1767. Les Premiers traits de l'Erudition Universelle, ou analyse abrégée de toutes les sciences, des beaux-arts et des belles lettres, par M. Le Baron de Bielfeld. T. 2. Leide: Chés Sam. et Jean Luchtmans.

Bikstu muiža. Nacionālās kultūras mantojuma pārvaldes Pieminekḷu dokumentācijas centrs (NKMP PDC), 4892: Nr. 5574.

Bruǵis, D. 2008. Die Herrenhäuser des Neoklassizismus in Lettland und ihre stilistischen Wurzeln in der Baukunst von Kurland und Livland. Klassizismus im Baltikum: neun Beitrage zum 5 Baltischen Seminar 1993. Lüneburg: Carl-Schirren-Gesellschaft, S. 143 (Schriftenreihe Baltischen Seminare Bd. 3).

Bruǵis, D. 1997. Historisma pilis Latvijā. Atk. izd. Rīga: Sorosa fonds-Latvija.

Chronik. 1925. In: Jahrbuch und Kalender des Deutschtums in Lettland 1926. Riga: Jonck \& Poliewsky, S. 109.

Deutsche und österreichische Bibliothekzeichen - Exlibris. Ein Handbuch für Sammler, Bücher- und Kunstfreunde. aus dem Buch- und Bibliothekswesen. 1901. Stuttgart: Julius Hoffmann.

Dišlere, I. 2013. Jaunpils muižas, muižin,as: Jaunpils novada muižu vēsture no 13. līdz 20. gadsimtam. Rīga: Atēna.

Fenelon, F. de Salignac de la Mothe. 1730. Les Aventures de Télémaque, fils d'Ulysse. Nouv. édition. Paris: Bartelemy.

Gemartert und ermordet. Liste Nr. 1. 1919. Rigasche Zeitung, Nr. 22, 20. Jun., S. 5.

Izcel̦ojušo vācu tautības pilson, saraksts: ziṇas par personām, kas izcel̦ojušas saskañā ar līgumu par vācu tautības Latvijas pilson,u pārvietošanu uz Vāciju: (Lik. kr. 1939. g. 176.): oficiāls izdevums. 1940. Rīga: lekšlietu ministrijas administratīvais departaments.

Lancmanis, I. 2019. Arhitektūra 1780-1840. Latvijas mākslas vēsture. 3. sēj. 1. grām. Klasicisma un romantisma periods 1780-1840. Rīga: Latvijas Mākslas akadēmijas Mākslas vēstures institūts; Mākslas vēstures pētījumu atbalsta fonds, 261. Ipp.

Lapiņš, J. 1929. Kārlis Kundziņš sen. Atskats uz dzīvi un 60 gadu literārisko darbību. Izglītības Ministrijas Mēnešraksts, Nr. 1, 3. Ipp.

Lielinieku upuri. 1919. Lìdums (pielikums), Nr. 16, 26. jūnijs, 18. Ipp.

Mašnovskis, V. 2018. Muižas Latvijā: vēsture, arhitektūra, māksla: enciklopēdija. 1. sēj.: A-H. Rīga: DUE.

Melderis, G. 1949.-1959. Jelgavas vēstures materiāli: izraksti un piezīmes. Rīga, LNB RXA52,9.
[Nachruf]. 1924. Rigasche Rundschau, Nr. 252, 5. Nov., S. 7.

Pārskats par kultūras vērtību aizsardzības darbiem Kurzemē, 1919. gada decembris - 1920. gada februāris. LNA LVVA, 1632. f. (Izglītības ministrijas sarakste ar Arhīvu-bibliotēku nodaḷu par arhīva dokumentu reevakuāciju), 2. apr., 935. I., 2. Ip.

Petri, J. Ch. 1809. Neue Pittoresken aus Norden, oder Statistisch-historische Darstellungen aus Lief-Ehst- und Russland: nebst einer Topographie von Moskau. 2., stark vermehrte Aufl. Erfurt: Knick und Müller.

Piilmann, S., Becker, P. G. 2002. Baltische Wappenexlibris: Exlibris der Ostseeprovinzen: Estland-KurlandLivland-Ösel. Tallinn; Gütersloh: [b. i.].

Pirang, H. 1926. Das Baltische Herrenhaus. Bd. 1: Die älteste Zeit bis um 1750. Riga: Jonck \& Poliewsky.

Pirang, H. 1928. Das Baltische Herrenhaus. Bd. 2: Die Blütezeit um 1800. Riga: Jonck \& Poliewsky.

Die Preisausschreiben des Jahres 1912-13. 1913. In: Jahrbüch fur Bildende Kunst in den Ostseeprovinzen. 7 Jg. Riga: Architektenverein zu Riga, S. 81.

Retz, J. F. de. 1719. Mémoires du cardinal de Retz: contenant Ce qui s'est passé de remarquable en France pendant les premières années du Règne de Louis XIV. Tome 1., 3., 4. Nouv. ed. Amsterdam: Chez J. Frederic Bernard, et H. Du Sauzet.

Ropp, M. A. v. d. 1926. Baltische Künstler in Deutschland. In: Jahrbuch des baltischen Deutschtums 1927. Riga: Jonck \& Poliewsky, S. 146-151.

Ropp, M. A. v. d. 1907. Das baltische Landhaus. Düna Zeitung, Nr. 172, 27. Jul. (9. Aug.), S. 2; Nr. 173, 28. Jul. (10. Aug.), S. 2.

Ropp, M. A. v. d. 1924. Deutschbaltische Malerei und Graphik. Ausstellung im Kunstmuseum. Rigasche Rundschau, Nr. 16, 19. Jan., S. 10.

Ropp, M. A. v. d. 1921. Eines Philosophen Reisetagebuch. Rigasche Rundschau, Nr. 165, 26. Jul., S. 5.

Ropp, M. A. v. d. 1907. Elkesragge: ein baltischer Zeitroman. Berlin: Egon Fleischel \& Co.

Ropp, M. A. v. d. 1908. Elkesragge: ein baltischer Zeitroman. 2. Aufl. Berlin: Fleischel.

Ropp, M. A. v. d. 1923. Das Recept des Wet-Heng-Pong. Rigasche Rundschau, Nr. 211, 24. Sept., S. 6; Nr. 212, 25. Sept., S. 6.

Ropp, M. A. v. d. 1928. Südafrikanische Bevölkerungsprobleme. Rigasche Rundschau, Nr. 161, 21. Jul., S. 9; Nr. 167, 28. Jul., S. 5; Nr. 173, 4. Aug., S. 5. 
Sarakste ar Izglītības ministriju par Valsts bibliotēkas pārvaldīšanu, 1925-1941. LNA LVVA, 235. f. (Latvijas Republikas Kultūras ministrijas Latvijas Nacionālā bibliotēka, 1919-1995), 1a. apr., 5. I., 182.-184. Ip.

Schlau, K. O. 1999. Bolschewikenzeit in Mitau: 9. Januar 18. März 1919. Wedemark-Elze: Harro v. Hirschheydt. (Beiträge zur baltischen Geschichte; Bd. 18.)

Sitzungsberichte der Gesellschaft für Geschichte und Alterthumskunde der Ostseeprovinzen Russlands aus dem Jahre 1894. 1895. Riga: W. F. Häcker.

Sitzungsberichte der kurländischen Gesellschaft für Literatur und Kunst, 1876. 1877. Mitau: J. F. Steffenhagen und Sohn.
Verzeichniss der Mitglieder der Section für Genealogie, Heraldik und Sphragistik in Mitau. 1893. In: Jahrbuch für Genealogie, Heraldik und Sphragistik, 1894. Mitau: J. F. Steffenhagen und Sohn, S. 176.

Vičs, A. 1922. Irlavas skolotāju seminārs. Izglītības Ministrijas Mēnešraksts, Nr. 11, 1136. Ipp.

Zaḷuma, K. 2019. Neredzamā bibliotēka: Latvijas Nacionālās bibliotēkas 14 vēsturiskās kolekcijas. Rīga: Latvijas Nacionālā bibliotēka.

Zilgalvis, J. 1995. Latvijas muižu klasicisma arhitektūra. Latvijas Vēstures Institūta Žurnāls, Nr. 1, 24.-38. Ipp. Иваск, У. Г. 1905. Описание русских книжных знаков: (Ex-Libris). Вып. 1. Москва: М. Я. Параделов. 